\title{
Egy gyermekcsoport szerepe a családsegítésben részesülő családokban nevelkedő hátrányos helyzetű gyermekek körében 1995-2005 között
}

\author{
SIK DOROTTYA ${ }^{1}$
}

\begin{abstract}
ABSZTRAKT
A tanulmányban egy 1995-2005 között müködő gyermekcsoport müködésének, gyermekekre gyakorolt hatásának az elemzése a korszakban megjelenő komplex és preventív családsegítés lehetôségeit és hatását mutatja be. A rendszerváltás utáni gazdasági és társadalmi hatások, a frissen kialakuló szociális ellátórendszer keretein belül ez a csoport a résztvevő gyermekek és családjaik számára nyújtott szolgáltatásokat és különböző ellátásokat. A program jelentőségét az adja, hogy egy olyan időszakban nyújtott prevenciós csoportos foglalkozást hátrányos helyzetü gyermekek számára, amikor az 1997. évi XXXI. számú A gyermekek védelméröl és gyámügyi igazgatásról szóló törvény még nem lépett hatályba, a gyermekvédelmi rendszer még nem alakult ki, nem határolták be a program müködését a jogszabályi keretek, a Családsegítő Szolgálat keretében múködő szolgáltatást szabadon lehetett alakítani a gyermekek és családok igényeihez.
\end{abstract}

KULCSSZAVAK: gyermekvédelem, prevenció, csoportmunka, szociális munka, rendszerváltás, megelőzés, gyermekjólét

\section{ABSTRACT}

\section{The role of a children group for the participant, underprivileged children} in the family care system 1995-2005

The aim of this paper is to analyse the methods and effects of a children group, which existed from 1995 till 2005. The relevance of this group is, that the beginning of this period preludes the constitution of the Hungarian child protection law. After the transmission period the emerging social service system provided (or at least tried) supports and services. Those families whose children were involved in this child group were dealing with unemployment, poverty, lack of proper housing, abuse, deviance and addictions. The significance of this group that the given service was easily ductile to the needs of the children and families.

KEYWORDS: child protection, prevention, group work, social work, transmission, child welfare

${ }^{1}$ ELTE TáTK Szociális Munka Tanszék, e-mail: sik.dorottya.borbala@tatk.elte.hu 


\section{TANULMÁNY}

\section{Bevezetés}

A cikk célja bemutatni egy, a rendszerváltás után működő gyermekek számára létrehozott csoportot, annak gyermekek életútjára gyakorolt hatását az 1997. évi XXXI. számú A gyermekek védelméről és gyámügyi igazgatásról szóló (továbbiakban Gyvt.) törvény előtti családsegítésre alapozó időszakból. A program jelentőségét az adja, hogy egy olyan időszakban nyújtott prevenciót csoportos foglalkozás keretében hátrányos helyzetű gyermekek számára, amikor a Gyvt.-vel hatályba lépett gyermekvédelmi rendszer nem alakult ki, nem határolták be a program működését a jogszabályi keretek, a Családsegítő Szolgálat keretében működő szolgáltatást szabadon lehetett alakítani a gyermekek és családok igényeihez. A csoportba heti rendszerességgel járó gyermekek száma 20-25 között mozgott, a 10 év alatt (1995-2005) összesen több mint 50 gyermek járt rövidebb vagy hosszabb ideig a csoportba. A csoport finanszírozása a Családsegítő Szolgálat által, illetve pályázati forrásokból történt. A csoportot a 10 év alatt több vezető páros, olykor trió irányította, folyamatos átmenetet biztosítva a csoport működésének. A kutatás során a korszakról fennmaradt dokumentumok másodelemzése mellett a kvalitatív módszereken alapuló kutatás során egy fókuszcsoportos beszélgetésen a tíz év alatt csoportot vezető nyolc szakemberből öt vett részt, továbbá részt vett a fókuszcsoportban a csoport kereteit biztosító családsegítő intézményvezetője is. A fókuszcsoportos beszélgetés mellett a csoportba járó gyermekek közül hat, ma már felnőtt, dolgozó fiatallal készült interjú. A megkérdezett fiatalok mind több éven keresztül, átlagosan 5 évig jártak a csoportba. Két fiúval és négy lánnyal készült interjú, életkoruk tekintetében ma húszas éveik közepén járnak. Jelenleg mindannyian dolgoznak, különböző területeken, mint vendéglátás, logisztika, gyári munka, illetve egészségügyi területeken. A megkérdezett fiatalok közül négy érettségizett és rendelkezik szakmával, ketten nem rendelkeznek középfokú végzettséggel, egynek felsőfokú diplomája van, ő egy magánóvodában dolgozik.

A gyermekcsoport környezetének a bemutatása után a csoport történetének ismertetése, majd a szakemberek és az érintettek véleménye alapján a csoport hatásainak az elemzése következik. A csoport hatásainak a megértését és értelmezését a résztvevő szakemberekkel és érintett fiatalokkal készült interjúk segítik.

\section{A gyermekcsoport környezete}

„A gyermekszegénység, akárcsak a szegénység általában, többdimenziós jelenség: a szegénység különféle dimenzióinak halmozódása jár együtt a gyermekek egészséges pszichés fejlődésének veszélyeztetettségével." (Darvas et al. 2002: 21) A rendszerváltás gazdaságban, foglalkoztatásban bekövetkezett változásaiból és a munkanélküliség növekedéséből következik a szegénység növekedése, a társadalom reáljövedelme és életszínvonala csökkent. A különböző hátrányos helyzetű csoportok nagy 


\section{TANULMÁNY}

arányban ki voltak téve az elszegényedés veszélyének: idősek, gyermeküket egyedül nevelők, fogyatékkal élők, romák, gyermekes családok, a kisebb, aprófalvas településeken élők, illetve az ország elmaradottabb régióiban élők. A rendszerváltás utáni évtizedben a jövedelmi olló szétnyílt, a társadalmi különbségek folyamatosan nőttek. A rendszerváltás nagymértékben megváltoztatta a magyar társadalom jövedelemszerkezetét az 1990-es években. Az átalakuló gazdaság és gazdasági válság hatására Magyarországon átalakult a magyar társdalom jövedelemszerkezete és a jövedelmi egyenlőtlenségek ugrásszerűen megnőttek (Sági 2009). Az 1995. évi egyenlőtlenségnövekedésnek különleges sajátossága, hogy a társadalmi különbségek lényegesen és folyamatosan nőttek a családok gyermekszámától függően, és a többgyermekes családok egyre inkább leszakadtak az országos átlagtól (Vukovich et al. 2006). A háztartások nagyságát tekintve és figyelembe véve a különböző szegénységküszöböket, a háztartás nagysága és a szegénység összefügg, a nagy háztartások (az öt személynél nagyobb háztartások) az átlagosnál nagyobb arányban szerepelnek a szegények között, illetve hogy bármely szegénységküszöb-mérést alkalmazva a gyermeküket egyedül nevelők, sokgyermekes családok magasabb arányban élnek a szegénységi küszöb alatt (Andorka et al. 2006). A TÁRKI adatai szerint az 1990-es évek első felében a jövedelemegyenlőtlenségek növekedésével egyszerre emelkedett a szegénységi ráta a teljes népességen belül. Gábos és Szivós tanulmánya alapján a szegénység 1995/1996-ban volt a legkiterjedtebb Magyarországon: a mediánjövedelem felénél megállapított küszöb mellett a lakosság közel 13\%-át, az átlagjövedelem feleként definiált küszöb esetében pedig mintegy 18\%-át tekintették szegénynek. 1996 után a szegénység kockázata csökkent Magyarországon. A 2003-as adatok szerint 2000 után Magyarországon a szegénység mértéke alig változott (Gábos et al. 2004, 2006).

A budapesti kerületről, ahol a csoport működött, kevés a rendszerváltás utáni időszakról rendelkezésre álló adat. A rendszerváltás előtt készült szociális térkép adatai alapján a kerületben 120 000-en éltek, a laksűrűség magasabb volt az országos átlagnál (42 000), a lakások egyharmada volt csak felújított (Hegyesi et al. 1990). A zsúfoltság, slumosodás, rossz lakásállomány, nem megfelelő minőségű levegő alapvetően határozta meg a lakosság életét és mindennapjait (Hegyesi et al. 1990). A 2001-es népszámlálás adatai szerint igen magas volt a komfortnélküli és szükséglakások aránya (Csanádi et al. 2006).

A Családsegítő Szolgálat megalakulásakor készített szociális térkép a következő, kiemelt szolgáltatást, segítséget igénylő társadalmi csoportokat állapított meg a kerületben: alacsony jövedelemmel rendelkező egyedülálló nyugdíjasok (a kutatás kiemelte alacsony jövedelem mellett a szociális izoláció is fontos, figyelembe veendő szempont) és párok, kétgyermekes többgenerációs családok (nagyszülőkkel kényszerből, zsúfoltan, alacsony jövedelemből éltek), illetve a „növekvő számban előforduló három- vagy többgyermekes családok minden tekintetben rendezetlen körülmények között (jövedelmük alacsony, életvitelük szegényes, a felnőttek nehéz fizikai 


\section{TANULMÁNY}

munkát végeznek, több közöttük a rokkantnyugdíjas, kapcsolataik vidéki rokonokhoz kötődnek, baj esetén csak rájuk számíthatnak, alapvető jogaikkal nincsenek tisztában, a komplex szociális segítségnyújtás itt hiányzik a leginkább)." (Hegyesi et al. 1990: 2)

A csoportba járó gyermekeket a rendszerváltás utáni legfontosabb társadalmi és gazdasági változások mind érintették: a foglalkoztatottsági helyzet megváltozása, a munkanélküliség és az anyagi problémák megjelenése, a lakhatási és az egzisztenciális nehézségek egyaránt. Ezek a családok a rendszerváltás előtt is küzdöttek anyagi problémákkal, korábban is nem megfelelő, állapotú és nem komfortos lakásokban éltek. Mind az oktatási, mind az egészségügyi területén nem jutottak megfelelő szolgáltatásokhoz. Hátrányaik, szegénységük a rendszerváltással hirtelen és drámaian erősödött fel. A rendszerváltás után megugró szegénység, a lakhatási és egyéb költségek emelkedése, a díjhátralék mint probléma ezeket a családokat felkészületlenül, váratlanul érte, tartalékok és erőforrások hiányában azonnal a társadalom perifériájára sodorta őket. A szülők körében a különböző devianciák és szenvedélybetegségek megjelenése, erősödése ennek a társadalmi változásnak, anomáliának a hatása is volt. A rendszerváltás után kialakuló szociális intézményrendszerek feladata volt az ezekre a problémákra való reagálás. Kerezsi 1996-ban a tovább fokozódó gazdasági nehézségekre hívja fel a figyelmet, és az ebből következő egyre romló szociálpolitikai feltételekre és támogatásokra, melynek eredményeképpen a társadalmi feszültségek növekedését és az egyenlőtlenségek erősödését prognosztizálta (Kerezsi 1996).

A rendszerváltás utáni időszak az ellátórendszer, szolgálatok kialakításának egy olyan speciális időszaka, amikor a „semmiből” kell kialakítani egy olyan sokproblémás helyzetre megfelelően reagáló szolgáltatási struktúrát, aminek korábban nem volt hagyománya Magyarországon. A gyermekcsoport ebben az időszakban jött létre azzal a céllal, hogy ezen társadalmi és gazdasági változások hatásait csökkentse a kerületi családsegítőn belül, amely megalakulásától komplex segítségnyújtást kívánt biztosítani a kerületi lakosoknak.

\section{A családok jellemzői}

A sokproblémás, halmozottan hátrányos helyzetű családokban felnövő gyermekek esetében a gyermek fejlődését befolyásoló különböző tényezők közül a pszichoszociális környezeti hatásoktól nem lehet eltekinteni. „A marginalitás egy többtényezős (multifaktoriális) pszeudoörökletes és önújrateremtő fogyatékosság." - Kende B. Hanna e szavakkal írja le a szocioökonómiai háttér jelentőségét a gyermekpszichodráma csoportok működésében (Kende 2003: 79). Kende a szegénység, az anyagi helyzet, a lakás- és egészségügyi körülmények mellett a családi kudarcokat, ellenségesnek érzékelt külvilágot, a külvilágra adott agresszív reflexeket, és az életstílus 


\section{TANULMÁNY}

kontinuitásának hiányát emeli ki (Kende 2003). A család jelentős hatást gyakorol a gyermek pszichológiai fejlődésére és kiemelkedő szerepe van a pszichés zavarok kialakulásában. Pszichiátriai kockázatok általában a gyermekek által érzékelt családi, személyközi viszonyokból származhatnak (Jenkins 2006). A gyermekek és fiatalkorúak szociális és érzelmi biztonságát, morális fejlődését az anyagi természetű problémák mellett a szülők/nevelők beilleszkedési zavarai, devianciái határozzák meg (Kerezsi 1996). Kerezsi szerint 1996-ban a hatóságoknál veszélyeztetettként nyilvántartott kiskorúak családjaira az átlagosnál nagyobb családnagyság és az atipikus családi struktúra volt a jellemző (Kerezsi 1996).

A kutatásban elemzésre kerülő gyermekcsoport a családsegítők korszakának a gyümölcse. Ebben az időszakban a sok problémával küszködő családokkal - a kialakuló gyermekvédelmi ellátórendszer és szolgáltatások hiányában - a családsegítők keretén belül, önkéntes alapon dolgoztak együtt a szociális munkások. A gyermekcsoport beágyazottan működött a családsegítő komplex szolgáltatásai között. A csoportba járó gyermekek többsége sokproblémás, krízisről krízisre élő családban élt, és a gyermekcsoport működésében a sokproblémás családokkal való munkának a nehézségei egyértelműen megjelentek.

\section{A csoport története}

\section{SZAKASZ: KIALAKULÁS (1995-1999)}

A csoport 1995 őszén indult, a családsegítő keretein belül. 1991-ben a Családsegítő Szolgálat azzal a céllal alakult, hogy az ott élő lakosságot támogassa az egyéni és családi problémáik kezelésében szociális, mentálhigiénés és terápiás szolgáltatásokkal. A csoport működésének időszakában a szociális ellátórendszer kialakulóban volt, kezdetekben gyermekjóléti szolgálat sem múködött a kerületben. A családsegítőben az egyéni esetkezelés, segítségnyújtás mellett csoportos és közösségi ellátások is szerepelnek a családsegítő eszköz- és módszerpalettáján. Közvetlen (esetkezelés, krízisintervenció, jogi és pszichológiai tanácsadás) és közvetett (szociális közösségfejlesztés, önsegítő csoportok támogatása) szociális munka mellett csoportok működtetése és a családok anyagi támogatása szerepelt. A különböző csoportok jelenléte szervesen illeszkedett a Családsegítő Szolgálat múködésébe, fontos célkitűzése volt az intézménynek a megelőzés, a prevenció. Ezen kiindulásból, hozzáállásból szervesen következett, hogy a családsegítővel kapcsolatban álló családok és gyermekeik számára a családsegítő 1994-ben nyári tábort szervezett. A táborba gyermekeket vártak, de már itt is megjelent az a mögöttes cél, hogy a gyermekeken keresztül a család egésze kap támogatást. „A tábor ötlete abból a felismerésből született, hogy a gyermekes családok támogatása - az adminisztratív ügyintézéseken és a családgondozáson túl - közvetlenebb módon, a szülői szerepek szociális helyzet- 


\section{TANULMÁNY}

ből adódó hiányosságainak korrigálásával is történhet." (Köhler et al. 1999: 12) A táborba olyan gyermekek jutottak el, akik számára az iskolák által szervezett programok, illetve nyári táborok és családi nyaralások megfizethetetlenek voltak. Ezeknek a gyermekeknek az életében a nyár egy végtelen és egyhangú időszak volt, amikor (a mindennapokhoz hasonlóan) nem hagyták el a kerületet, de igazából a környéküket sem. Alternatívák hiányában napjaikat az utcákon, játszótereken és a közeli parkban töltötték felnőtt felügyelet nélkül. A családsegítő munkatársaiban már az első tábor után felmerült az ötlet, hogy gyermekcsoportot hozzanak létre a táborban résztvevő gyermekek számára. A cél, hogy a nyár folyamán már kisebb közösséggé formálódott gyermekcsapatnak heti gyakoriságú találkozót szervezzenek, de ez a családsegítőben dolgozó szakemberek kapacitáshiánya miatt nem valósult meg. A következő évi nyári tábor még több gyermeket vonzott. A programok különféle kreatív, kézműves, drámajátékot alkalmazó foglalkozásokkal bővültek. 1995 őszén újból elkezdődött egy heti rendszerességgel működő csoport elindításának megszervezése, ekkor már sikerrel.

„Olyan magától értetődő volt, hogy a családokkal és a zürös gyerekkel találkozunk, és kéne valami jó kis nyári tábor, az volt a felismerés a második tábornál, hogy nem jó, hogy ott akkor megszakad és csak nyáron van valamiféle kapcsolat... További élményátadásra lenne szüksége a gyerekeknek, és hogy kellene valami a két tábor között is." (Intézményvezető)

A sikeres csoportinduláshoz szükséges volt a családsegítőnek mint intézménynek az elkötelezettsége a csoport megszervezése mellett. Ugyanakkor tanulva az előző év tapasztalatából, ez nem volt elegendő feltétele a csoport beindításának. Az intézménynek ekkor szoros kapcsolata volt az egyik szociális munkás képzőintézménnyel. Amikor felmerült a lehetőség a gyakorlatban kipróbálni az egyetemen elméletben tanult csoportozást mint segítő műfajt, a csoportvezetést külsős, még egyetemista szociális munkás hallgatók vállalták (Köhler et al. 1999).

A csoport céljait a táborok tapasztalatai és a gyermekekről, családokról rendelkezésre álló információk alapján az akkori vezetők alakították ki. Ezen célok egy része előre látható és tervezhető volt, míg egy másik részét menet közben a csoporttagok igényei és problémái, erősségei és nehézségei alakították, változtatták. A családsegítő adottságai nem tették lehetővé az ottani „csoportozást”, így külső helyszínt kellett keresni, ezután kezdődhetett a tagok toborzása. Az első helyszínen az intézménybe való bejutás csak a portással együtt volt megengedett, ez a készen kapott szabály elfogadása volt az első. A későbbi, változó helyszíneken is jelentős volt a portások szerepe, az ő hozzáállásuk meghatározó volt, s a gyermekek már a találkozók előtt a helyszín előtt várakoztak. 


\section{TANULMÁNY}

„A gyerekek udvaron kosaraztak, ott vártak minket, a portás ebben partner volt, ez fontos, hogy vártak ránk." (csoportvezető 1)

Az első alkalmak a további intézményi szabályok megismerésével és elfogadásával, illetve a saját csoportszabályok kitalálásával teltek. A csoport létszáma stabil volt: a kilenc törzstaghoz az első években egy-két testvér csatlakozott, később a csoport létszáma 10-15 főre bővült. Előfordult ennél magasabb csoportlétszám is átmenetileg, de a 15 fő körüli létszám volt a legideálisabb a csoport szempontjából. Abban az értelemben mindig nyitott maradt a csoport, hogy egy-egy tag csapódott a csoporthoz, de egy összeszokott törzsgárda, mag alkotta mindvégig a Játszóházba járó gyermekek csoportját, az újak legtöbben a gyermekek közvetítésével érkeztek.

„Egyre több családtag bevonódott, hozták a testvéreket, az osztálytársakat, kirándulásokon keresztül szivárogtak be a csoport életébe." (Csoportvezető 2)

A következő nyáron újabb tábort szervezett a Családsegítő Szolgálat, amelyen a csoportba járó gyermekek is részt vettek, ám a csoport akkori vezetői nem. A következő év a nyári táborban készült videó megnézésével kezdődött, ez innentől hagyománnyá nőtte ki magát a csoport életében. A nyári táborban részt vett egy kézműves szakember, aki vállalta, hogy ősszel, havonta egyszer kézműves foglalkozást tart a csoportnak. Idővel ez a kézműves szakember részben vezetőként, részben kézműves mesterként a csoport állandó tagjává vált. Az ő személyében nemcsak egy olyan szakember csatlakozott a csoporthoz, akinek köszönhetően a kézműves foglalkozások tárháza bővült, de az apa-nagyapa mintaadó szerepével, nyugodtságával, türelmével olyan kapcsolódási pontot tudott nyújtani - főleg a fiúknak -, ami túlmutatott a kézműves foglalkozáson (Köhler et al. 1999).

A második évtől három vezetővel indult el a csoport és ez a felállás 1999-ig változatlanul működött. 1997-től a csoport vezetői szervezték a nyári tábort a csoportba járó gyermekek és testvéreik számára. A szülőkkel való kapcsolat a táborok szervezése során megerősödött, így több információval rendelkeztek a csoportvezetők, ami megkönnyítette a csoportmunkát, illetve a gyermekkel való foglalkozást.

„Minden összerakódott, fontos a hátteret látni, ahogy megismertük a családokat." (Csoportvezető 2)

Ez az első szakasz tehát a csoport kialakulásnak fázisa volt. A csoportvezetők célja a rendszeresség, a heti találkozások kialakítása, továbbá a végleges vezetői gárda és a kezdeti csoportszabályok kialakulásának a folyamata volt. 


\section{TANULMÁNY}

„Nem volt felépítve hosszútávú cél, az első években nem volt így koncepció, de utána a kirándulások szervezése, majd a táboroké már az építkezés része volt, karácsonyi müsorok, programok is egy fejlődési út voltak." (Csoportvezető 2)

\section{SZAKASZ: ÉLETKOR SZERINTI SZÉTVÁLÁS, PÁRHUZAMOS CSOPORTOK (1999-2001)}

A Játszóháznak különleges színezetet adott, hogy ott a gyermekek többsége testvérével együtt volt tagja a csoportnak. A csoport működése alatt több mint tíz testvérpár/hármas/négyes testvérsor fordult meg a Játszóházban. A testvérpárok egy része már az első táborokban közösen vett részt, míg az évek alatt több olyan család is volt, ahol a kistestvérek belenőttek a csoportba. A testvérkapcsolatok csoportban való kezelése a csoport múködése alatt mindig nagyon nehéz kérdése volt. Előnye és hátránya egyaránt volt annak, hogy a kialakulásától kezdve így szerveződött a csoport. A testvéri kapcsolatok sokszor komoly feszültséget, konfliktusokat generáltak, az otthonról hozott problémák a csoportban robbantak. Mozaik családok esetében, ahol a testvérpárok régi és új kapcsolatokból vegyesen érkeztek, különösen gyakran a csoportban robbantak ki az otthon elfojtott feszültségek. Ugyanakkor a testvérek erőt, támaszt, biztonságot is nyújtottak egymásnak. A nagytestvérek tehermentesítődtek, mert a csoport ideje alatt nem kellett a kistestvérre vigyázniuk. Azok számára, akiket otthon szülői szereppel ruháztak fel, végre gyermekként élvezhették a csoport nyújtotta programokat (Köhler et al. 1999).

A Játszóház harmadik éve után a csoport fele életkorban már nagyon elkülönült a kisebbektől. A táborban a mindennapi történéseken keresztül sokkal tisztábban megnyilvánultak a korkülönbségekből fakadó problémák, ekkor szembesültek a csoport vezetői a kamaszodó nagyok és a csoporttaggá váló kisebbek eltérő életkorból fakadó nehézségeivel. Bár ez egy természetes folyamat volt, mégis váratlanul érte a csoportvezetőket, hogy az életkori sajátosságok szétfeszítették a csoport kereteit. A csoport több éven át tartó alakulására leginkább az volt a jellemző, hogy idővel a régi tagok hűségének köszönhetően a csoportba járók életkora ugyan nőtt, de a csatlakozó kisebb korosztály bekapcsolódásával az átlagéletkor mégsem változott meg jelentősen. A csoport indulásakor a gyermekek életkora hattól tizenegy évig terjedt, ez három év elteltével ötévestől tizenöt évesig tágult.

„A kistestvérek már alig várták, mikor jöhetnek először táborba, csoportba, sokszor már óvodás korút is elvittünk." (Csoportvezető 3)

Ez már olyan hatalmas különbséget jelentett a gyermekek között, amely gyengítette a csoportkohéziót és megkérdőjelezte a csoport egységes célját is. Az egykor adottságként kezelt nagy korkülönbséget, ahogy ez tovább tágult, már nem lehetett 


\section{TANULMÁNY}

kézenfekvőnek tekinteni, elkerülhetetlen lett a csoport működésének újraértékelése. A csoport heterogenitása előny volt, de eljött az a pont, amikor ez az előny a csoport múködése és a csoporttagok szempontjából hátránnyá, veszéllyé változott. A csoportlétszám ekkor alkalmanként meghaladta a tizenöt-húsz fót, egyre több pici került a csoportba. A törzstagok szinte elvesztek a csoportban, és a picikre fordított idő meghaladta a nagyok tűréshatárát. Eleinte spontán, különböző feladatokkal, foglalkozásokkal és játékokkal két részre osztódott a csoport, de egyértelművé vált, hogy formálisan és strukturálisan is meg kell történnie a csoport szétválásának. A csoportvezetők döntése alapján a megváltozott igényekre és szükségletekre reagálva, két, párhuzamosan múködő csoport lett volna a kitűzött cél. Abból a megfontolásból, hogy a két csoport egyidőben egyfajta folyamatosságot nyújt a tagoknak, lehetséges olyan közös alkalmakat találni, amikor a közös hagyományokat, ünnepeket együtt lehet megtartani. A foglalkozások és a nyári tapasztalatok alapján a serdülőknek több dramatikus és kevesebb kézműves foglalkozást terveztek a csoportvezetők, egy új negyedik csoportvezető csatlakozásával alakult ki a két csoport (Köhler et al. 1999). A régi csoportvezetők a kamaszcsoportot vitték volna tovább, az új csoportvezető és a kézműves szakember vitte volna tovább a kicsik csoportját. A tervekkel ellentétben a gyakorlatban nem tudott megvalósulni ez a müködési mód. Az új kiscsoportok keretei, határai nem tudtak megszilárdulni, a tervezett átjárhatóság és folytonosság meggátolta ezt a folyamatot.

„A gyerekek nem tudták elfogadni a párhuzamosan futó két csoport kereteit, folyamatosan áthágták a szabályokat, átmentek a másik csoportba." (Csoportvezető 1)

Annak ellenére, hogy a kisebbek csoportba való eljutásának feltétele volt, hogy nagytestvérek hozzák őket - ez fontos szempont volt a két párhuzamosan futó csoport kialakításakor - a kiscsoportok inkább csak egy-egy feladatra, játékra korlátozódva, alkalomszerúen múködtek. Ennek ellenére a négyes vezetés megmaradt, a különböző programok, feladatok mentén az elkülönítés, életkor szerinti különbségek figyelembevétele megtörtént annak ellenére, hogy effektív új kiscsoportok nem alakultak ki, nem szilárdultak meg.

„Azt éreztük, hogy mást kellene csinálni a nagyokkal, drámázni, más foglalkozásokat, de a csoport kettébontása végül nem valósult meg, próbálkozás volt, de nem lehetett őket szétszedni, átrohangáltak." (Csoportvezető 1)

A szülókkel való kapcsolatfelvétel mentén felmerült ötletként a párhuzamosan futó gyermekcsoport mellett müködő szülőcsoport lehetősége. A családsegítőben dolgozó egyik kolléga lett volna ennek a csoportnak a vezetője, volt is próbálkozás, de a szülők időbeosztása, nehézségei, kisebb testvérek mellett ez a csoport nem tu- 


\section{TANULMÁNY}

dott elindulni. Az elképzelés illeszkedett abba a koncepcióba, amely a család egészében gondolkodva tervezett változást a gyermekek érdekében. A szülők támogatása, megsegítése tovább erősítette volna a gyermekek körüli támogató közeget.

„Szülőcsoport terv is volt, de nem sikerült a szülőket bevonni, becserkészni, nem volt jellemző, hogy jöttek volna, egy-egy szülő jött barátkozni, hogy ő beszélgethessen." (Csoportvezető 2)

\section{SZAKASZ: SZÉTVÁLÁS, ÚJRASZERVEZŐDÉS (2000-2003)}

Mind a csoporttagokat, mind a vezetőket kimerítette ez a helyzet, ami viszont sértette a Játszóháznak azt az alapelvét, mely szerint a Játszóház maga a biztonságot nyújtó menedék, állandóság, stabilitás. Nem sikerült megszilárdulnia a két párhuzamosan futó csoportnak, a bizonytalan állapot elhúzódó állandóvá vált. Ezzel egy időben a helyi önkormányzat célul tűzte ki, hogy létrehoz egy olyan ifjúsági klubot, amely a kerületi kamasz korosztály számára biztosít helyet, programokat, megelőzendő a csellengést és az ebből fakadó különböző kockázatokat. Felmerült tehát az ötlet a sikertelen párhuzamos csoportok helyett, hogy a nagyok, kiöregedvén a csoportból, legyenek az újonnan kialakuló ifjúsági klub bázisa, kezdő csapata. Mind tematikájában, mind megcélzott szolgáltatásaiban, célcsoportjában ideálisnak tűnt ez az új intézmény a kamaszok számára. Minden csoportvezető egyetértett abban, hogy akkor tudjuk biztonsággal elengedni ezeknek a gyermekeknek a kezét, ha van kinek átadni őket. Az akkor már évek óta csoportba járó idősebb gyermekek számára egy nehéz folyamat volt a csoportból való távozás, ami az ősz folyamán az egyre ritkuló közös alkalmak sorozatával történt meg. A kialakuló ifjúsági klub számára az önkormányzat nem biztosított helyiséget, s a foglalkozási helyek átmenetisége, állandó váltakozása miatt ez a szolgáltatás végül nem tudott elindulni a kerületben, így a csoportból kikerülő fiatalok kikoptak a klub életéből, majd maga a klub sem maradt meg mint szolgáltatás a kerületben.

„Ez egy nagyon szomorú történet, esélyt se kaptak, hogy kipróbálják magukat." (értsd: a klub dolgozói) (Csoportvezető 3)

A nagyobbak kiválásával egyidőben személyi változások is történtek a Játszóház vezetői körében. A csoportból kiváló nagyok testvérei jelentették a folytonosságot, de ebben az időszakban új tagokkal bővült a csoport. Az új vezető korábban már a táborokban részt vett, így nem volt új a gyermekek számára. Az egyik csoportvezető belsős kollégaként dolgozott tovább. A belső vezetés a szülőkkel folytatott munkában okozott előrelépést, amitől a csoport egyre jobban beágyazódott a családsegítő müködésébe, de a nagy gyermekek leválása, a helyszínváltások miatti kényszerű költözések krízist okoztak a csoport életében. 


\section{TANULMÁNY}

„2000 ősszel még egyben volt a csapat, ott törés, újra kellett csapatot építeni." (Csoportvezető 4)

Ebben az időszakban még egy fontos változás történt a Játszóház életében, azzal, hogy az eddig külsősként dolgozó csoportvezetők egyike a családsegítőben kezdett dolgozni, és a csoport vezetése, szervezése mellett az lett a feladata, hogy a csoportba járó gyermekek családjaival is foglalkozzon, esetmunkát is végezzen. Ebben az időszakban bár már elindult a kerületben a gyermekjóléti szolgálat, azokkal a családokkal, akik korábban a családsegítővel álltak kapcsolatban, továbbra is a családsegítő foglalkozott. A gyermekjóléti szolgálat megerősödésével, ismertségével, intézményrendszerben betöltött funkciói kialakulásával párhuzamosan ez a későbbiekben változott, a családsegítőből a gyermekes családok esetei átkerültek a gyermekjóléti szolgálathoz. Ebben az átmeneti időszakban fontos volt, hogy ezek a családok kapcsolatban maradhassanak az általuk megszokott, ismert intézménnyel és kollégákkal. Ez a változás jelentősen befolyásolta a Játszóház és a szülők kapcsolatát, a belsős vezető sokkal több információval rendelkezett a családokról és a gyermekekről, az információáramlás oda-vissza jobban működött.

Régi és új gyermekekkel, három vezetővel - megtartva a korábbi évekre jellemző kereteket - változatlan hagyományokkal, szabályokkal és normákkal folytatódott tovább a csoport működése, s változatlanul magas (15 körüli) volt a heti gyermekszám, továbbá megmaradtak a nyári táborok. Ebben az időszakban hármas vezetéssel működött a csoport, a nagyok távozásával, az életkori differenciálásra való igény megszűnésével ez elégséges volt.

„Kialakult közöttünk egy vezetői kör, olyan mintha egy burok lett volna a Játszóház körül, változtak vezetők, de a burok egységes maradt." (Csoportvezető 4)

A csoport körül meglévő vezetői csapat, akik elfoglaltságuktól, személyes életük alakulásától függően különböző mértékben vettek részt a csoport életében, biztonságos keretet adtak a csoport működésének. A gyermekek számára egyértelmű volt, kire mikor lehetett számítani, az új vezetők érkezése, a régiek távozása is mindig folyamatként és nem váratlan eseményként érte a gyermekeket.

A csoport kialakulásakor a szülőkkel és a családsegítővel kevés kapcsolata volt a csoportvezetőknek. A gyermekek jobb megértése érdekében szorosabbra kellett húzni a szálakat mind a szülőkkel, mind a családsegítőben dolgozó, családokkal foglalkozó kollégákkal. Egyértelművé vált a csoportvezetők számára, hogy a gyermekekkel való sikeres munka nem tud megvalósulni a szülők, a környezet, az aktuális nehézségek megismerése nélkül. A családsegítővel kialakult kapcsolat mindkét fél munkáját nagyban könnyítette és a családi rendszer egységként jelent meg mind a családgondozó, mind a csoportvezetők előtt, nyomon követhetővé vált, hogy az 


\section{TANULMÁNY}

egyéni, illetve a csoportos segítő eszközök hogyan befolyásolják a család, és ezen belül a gyermekek életét. Az egymásnak adott visszajelzések megkönnyítették a munkát mindkét fél számára, ami hosszútávon a családok és a gyermekek szempontjából is nagyon előnyös változás volt a szakmai munkában. A szorosabb együttműködés a szülőkkel elősegítette a családok alaposabb megismerését. A belsős csoportvezetés megjelenésével 2001-ben új fejezet nyílt a csoport életében. Ekkorra a Játszóház közvetítő csatornaként funkcionált a család és a családsegítő között. A családok felkeresése, működésük, rendszerük megértése természetesebb módon, könnyebben tudott megvalósulni, s játszóházi kapcsolatuk miatt ők is könnyebben fordultak a családgondozóhoz. A családokra jellemző volt, hogy így közlékenyebbé váltak, a különböző nehézségek, gondok könnyebben megoldhatóvá váltak. A korábbi években egyes esetek, elakadások mentén megvalósuló kapcsolat, a csoportvezetők egy-egy teamen való részvétele a belsős vezetés következtében sokkal szorosabbá, intézményesültebbé vált. Ez a csoport életében erősödést jelentett, s könnyebbé tette a kapcsolódást a családokhoz. A személyi és csoportbeli változások után a Játszóház újabb fellendülése, „második virágkora” a belső vezetésnek volt köszönhető.

„Igen, könnyebb volt kapcsolódni így ezekhez a családokhoz, de sokszor a kettős szerep megnehezítette a dolgom." (Csoportvezető 4)

A külső vezetés hátránya, hogy a csoportvezetők lazán kapcsolódtak az intézményhez, az együttműködés formális, rendszertelen és időszakos volt a csoportvezetők és az intézmény között. Így előfordult, hogy elvesztek információk, nem értek össze a szálak, amik hasznosíthatók lehettek volna az egyéni esetkezelésben. A tábori és év közbeni tapasztalatok visszajelzése a családgondozók felé gyakran okozott konfliktust, a családgondozók nem tudtak mit kezdeni az információval, nehezen tudták képviselni a játszóházi tapasztalatokat, hiszen nem első kézből származtak az információk. A másodkézből kapott információk torzulhattak, a segítők nehezen tudták használni ezeket az információkat, hiszen nem saját tapasztalataik voltak. A gyermekcsoport vezetői viszont kimaradtak a visszajelzés, visszacsatolás folyamatából, s bennük emiatt erős hiányérzet maradt. A belső vezetés ezeket a nehézségeket kiküszöbölte. Az egyéni esetkezelés, illetve a csoportban végzett munka egymást kiegészítve egy rendszerben zajlott. A belső vezető ismerte a gyermekek körüli mikro-, mezo- és makrokörnyezetet, a különböző intézmények és a család viszonyrendszerét, rendszeresen mozoghatott az érintett terepen, hatékonyabban tudott kommunikálni a szervezetek között és szervezeten belül.

„Szerettem ezt csinálni, jó volt minden szinten dolgozni velük, nem csak gyerekkel, sok szülő jött be hozzám. Tudták hol találnak meg, ott voltam, utcákon is lehetett együtt dolgozni." (Csoportvezető 4) 


\section{TANULMÁNY}

\section{SZAKASZ JÁTSZÓHÁZ KIFUTÁSA (2003-2006)}

A vezetői „burok” 2006 körül eltűnt a csoport körül. A csoportot vezető szakemberek máshol kezdtek el dolgozni, családi okok miatt nem tudtak már sem heti rendszerességgel, sem alkalmilag részt venni a csoport életében. A végén a megmaradt vezetők, bár az intézmény dolgozói voltak, már nem tudták ezt a vezetői közösséget fenntartani, nem jött vezetői utánpótlás és a csoport lassan elhalt.

„Nem tudtam együtt dolgozni a kollégával, nem ugyanazon a hullámhosszon beszéltünk. Átment valamibe, ami nekem se jelentett semmit." (Csoportvezető 5)

A csoport története magának az intézménynek az átalakításával ért véget, illetve a gyermekjóléti szolgálat, ahogy egyre hatékonyabban tudott működni, átkerültek az esetek, és a családokkal való kapcsolat is átkerült a gyermekjóléti szolgálatba. Innentől kezdve az ottani kollégák ismerték a gyermekeket, családokat, így ott más formában, más módon folyt a szakmai munka. A Játszóház mint csoport, tudás, know-how nem tudott átkerülni, az intézmények közötti résben elveszett, a benne dolgozó kollégák nélkül a szellemisége elhalt.

„És amit nem sikerült megfogalmazni, mi volt a koncepció szelleme, mi az, ami múködtette, de valami volt, ami múködtette a dolgot és a végén az már nagyon más volt, a foglalkozás került elötérbe, míg korábban az egy aktivitási keret volt." (Intézményvezető)

\section{A JÁTSZÓHÁZ CÉLJA ÉS GYERMEKVÉDELMI JELENTŐSÉGE}

$$
\text { Élmények - hagyományok - ünnepek }
$$

Az egyik alapvető, a kezdetektől, az indulástól fontos cél volt az egyébként ingerszegény környezetben élő, csellengő gyermekek számára az élmények átadása. Ide sorolva a kézműves foglalkozásokat, tábori programokat, Budapest környéki kirándulásokat. Fontos jellemzője volt a csoportnak, hogy ezek az élmények, foglalkozások egy része alapvető, megkérdőjelezhetetlen hagyománnyá nőtte ki magát mind a csoporttagok, mind a csoportvezetők számára is.

„A bögrefestés, a képeslap volt az első minden évben a táborban más és más technikával, ez volt a kezdő lépés és a gyöngyözés is, ezek nagyon fontosak voltak mindenkinek, nemcsak a gyerekeknek." (Csoportvezető 1) 


\section{TANULMÁNY}

„Írunk mesét, kimennek az erdőbe, nem vágják ki a fát, hanem ott díszítik, hazajöttünk és nem vágtunk ki fát..." (Csoportvezető 1)

\section{A gyermekekhez kapcsolódó nehézségek kezelése}

A csoportozás, a csoportokkal való munka kihívásai komoly nehézséget, dilemmát jelentettek. A csoport a gyermekeknek szólt, de a vezetők számára még egyetemistaként, majd kezdő szakemberként fontos tanulási folyamatot és mérföldköveket jelentett. A legnehezebb dilemma mindig a csoport versus egyén kérdése volt. A beszélgetés során erre hangsúlyosan tértek ki az egykori csoportvezetők. A foglalkozásokon teret kellett adni azoknak a destruktív érzéseknek, amiket a gyermekek ki szerettek volna adni magukból. Ilyen volt a gyurmából, agyagból alkotás helyett a kulagyártás.

Ezt a viselkedést a csoportvezetők megengedték (főleg a fiúkra volt jellemző). A csoportvezetők hagyták, hogy kiengedjék magukból a bennük feszülő érzéseket, agressziót. Ez a hozzáállás, szemlélet nagyon fontos megtartó erőnek bizonyult és fontos feszültséglevezetés volt a csoporttagoknak. Visszatekintve fontos csatorna volt a játszóházi csoport azzal, hogy nem lettek letiltva ezek az érzések, ki lehetett őket fejezni, az évek alatt konstruktívvá lehetett alakítani. Az évek alatt egyre többször voltak képesek ezek a gyermekek alkotni agyaggal kulajátszás helyett.

„Másik gyerek, depresszív tünetek, szupervízióba vittük, nála volt territórium megjelölés (értsd: odaszékelt), nagyon megdöbbentő volt, foglalkozásokon ez szelídült kulagyártássá." (Csoportvezető 3)

\section{Holding funkció}

Sokszor nem volt tudatos a csoportvezetők számára sem, hogy az a stabilitás, a rendszeresség, az aktív jelenlét a gyermekek életében mennyire nagy jelentőségű. Az, hogy biztos pontként állt életükben a péntek délután, a várt programok, a tábor olyan megtartó erőt adtak nekik, amely az életükben lévő egyébként nehéz, lesújtó, élethelyzetet valamilyen mértékben egyensúlyozta, élhetővé tette.

„Valahogy ez a normalizálás, hogy az összes szörnyüség hatott ránk... és ettől volt egyfajta elfogadás, de nem ez a hüha, hanem az a holding, hogy mi is kibírjuk." (Intézményvezető)

„Az elfogadás, ebben egység volt, mindenkit tökre szerettünk, ebben a holdingban, hogy ott voltunk hosszú évekig és átadtuk, és sok évig volt ez a fajta tartás, az már önmagában erősít." (Csoportvezető 2) 


\section{TANULMÁNY}

\section{A realizálható világ}

A csoport keretei, határai, a megszokott feladat és foglalkozások és az újdonságként ható programok megfoghatóvá, megismerhetővé tették a gyermekek számára a világot. A csoport végig azon a sávon mozgott, amely kellő kereteket adott, hogy múködőképes legyen, de kellően tág is ahhoz, hogy a nagyon szélsőséges viselkedésű gyermek is beleférjen.

A világ realizálhatóságának egy emblematikus példája, amikor egy olyan településen volt a nyári tábor, ahol semmilyen bolt, vendéglátóipari helység nem volt megtalálható. A táborba érkező gyermekek kaptak zsebpénzt, ami nagyon ritka és nagy dolog volt számukra. Nem fordult elő gyakran, hogy ők pénzzel rendelkezzenek és arról szabadon dönthessenek. Érezhető volt, hogy rendkívül fontos számukra, hogy a kis pénzüket elkölthessék arra, amire ők szeretnék és nagyon csalódottak voltak, hogy nincs erre lehetőség. A táborvezetők érezve, hogy erre a helyzetre reagálni kell, úgy döntöttek eljátsszák a faluból hiányzó boltot, áruval, kasszával, minden szükséges szerepkellékekkel. Ez egy spontán intuitív döntés volt részükről, de visszatekintve a beszélgetés során is megerősödött a csoportvezetőkben ennek a jelentősége.

„Ami nekem néha keretek nélküli volt, bennünk ugyanakkor jól jött, mert ez egy realizálható világ volt.” (Csoportvezető 1)

„A bolt erős szimbóluma annak, amit csináltunk: a táborhelyen nem volt bolt, a gyerekek el akarták költeni a zsebpénzüket, így csináltunk és mindenkinek volt szerepe és ez fontos jellemzője a müködésünknek, ami kifejezett minket." (Csoportvezető 5)

\section{Csoportvezetők személyisége, burok}

Az a tény, hogy a csoportvezetőkből és a további csoporthoz és táborokhoz lazábban kapcsolódó emberekből egy olyan burok tudott kialakulni a csoport körül, ami ezt a holding funkciót biztosítani tudta, elengedhetetlen és szerves része van abban, hogy ez a csoport ennyi éven keresztül jól működött. Egyszerre jelent meg a csoport határképzése és a határtalanságból fakadó szabadság. Benne voltak a vezetők a csoportban a személyiségükkel, hibáikkal, pozitív tulajdonságaikkal, személyes történeteikkel, ami szintén erőt adott a gyermekeknek. A teljes elfogadás nagyon fontos alapelv volt, nem számított, hogy otthon vagy iskolában hogyan ítélik meg őket, mi a szerepük, akkor és ott csak az ottani viselkedésük számított.

„Ki kell mondani, hogy fontos volt ez a személyiség, belefért sok minden.” (Csoportvezető 1) 


\section{TANULMÁNY}

„Öröm, felszabadultság - valami egész más, mint amit az iskola és a szülők közvetítettek." (Csoportvezető 3)

\section{A gyermekcsoport a résztvevő gyermekek perspektívájából - visszaemlékezések}

\section{Biztonság - stabilitás - jelenlét}

Kivétel nélkül minden beszélgetésben megjelent a csoport mint biztonságot, stabilitást nyújtó keret az életükben. A heti rendszeresség, a csoport, olyan pont volt az életükben, amire támaszkodtak, amit várhattak, amibe kapaszkodhattak. Az előző fejezetben taglalt holding funkció, ami a csoportvezetők számára az egyik alapvető célként fogalmazódott meg, a megkérdezett fiatalok narratívájában, történetében, visszaemlékezésében is az egyik legerősebb, legjobban megragadható szál. Ez a biztonság, megtartóerő elmondásuk alapján nem csak a csoport ideje alatt, hanem később is adott nekik erőt és kapaszkodót. A megkérdezettek narratívájában a biztonság, biztos pont, hely, a péntek a hét csúcspontja erőteljesen megjelenő kifejezések. Szinte mindenki említette a beszélgetés során, hogy a várakozás, hogy péntek legyen és eljöjjön a csoportba menés ideje, végigkísérte a hetüket. Ugyanez igaz a nyári szünetekre is, mindennapjaik kerete, viszonyítási pontja volt a csoport. Az interjúkban elhangzó jelzők mind ennek a holding funkciónak az eredményét, hatását mutatják: állandó, családias, nyugodt légkör. Szorosan ehhez az élményhez, érzéshez kapcsolják a csoportvezetőkkel való kapcsolat erejét és fontosságát: kedves, támogató, segítőkész, odaadó felnőttek. Az is egyértelműen kiderül az interjúkból, és alátámasztja a fókuszcsoportban elhangzottakat, hogy ez a fajta közösség, vezetői csoport egységesen jelentett a gyermekeknek megtartó erőt, hátteret. Nem nevesítődött egyes személyekhez a csoporthoz kötődés, nem egyes csoportvezetők személyes kapcsolata volt meghatározó, hanem az évekig tartó csoporthoz kötődés. Rákérdezve megemlítették a csoportvezetőket, név szerint felsorolva őket külön kérésre, de egységes burokként, vezetői csoportként, akik közösen és nem személyükben jelentették számukra a csoportot.

„Volt egy adott hely meg időpont, ahol vagy ... örülnék lenni, ha most is lenne ilyen, a fiamat kergetném oda. Jó irányba terelt, második család voltatok ti, ... ezért vagyunk olyanok, amilye nek, nem vagyunk irigyek, mindig adunk." (Gyerek 1)

„A Játszóház egy pénteki ikon volt ... segített beilleszkedni a közösségbe, elfeledtette velem azt, hogy honnan jöttem, segített abba, hogy gyerek lehessek. Segített azzá az emberré válni, aki ma vagyok." (Gyerek 2) 


\section{TANULMÁNY}

\section{Tudás - készség - kreativitás}

A megkérdezettek számára nagyon fontos és egyértelműen hosszú hatású, számukra pozitív változást, segítséget jelentő szempontként definiálták a csoportban szerzett tudások eredményét és hatását. A fókuszcsoportban elhangzottakhoz képest erőteljesebb hatásról számoltak be a fiatalok. A feladatmegoldó képességük, kézügyességük, kreativitásuk, ismereteik a csoport hatására fejlődött, a mai napig mindennapi feladatok elvégzésében, problémás helyzetek megoldásában segítik őket a csoportban megtanult készségek, képességek. A leggyakrabban ismételt jelzők a kreativitás, kitartás, tudás. Az a tény, hogy a megkérdezettek számára ez a hatás sokkal markánsabban jelent meg, mint az a fókuszcsoportból kiderült, mutatja, hogy a mintaadás, tudás és értékközvetítés erejét a segítők sokszor alábecsülik, ha olyan tevékenységekről van szó, ami számukra sokkal evidensebb, természetesebb, mint a klienseké. Sokszor az elért hatás nem kézenfogható, megragadható a segítők számára.

A fejlesztő, kreatív foglalkozások mellett a különböző társasjátékokat említették, amiket „jó volt sok másik gyerekkel játszani” (Gyerek 3).

A különböző kézműves foglalkozások közül a gyöngyfűzést és a bőrdíszműveskedést emelték ki mindannyian meghatározó emlékként.

„Játszottunk mindig valami kreatívat, hajtogattunk, gyurmáztunk, kézmüveskedtünk - bördíszmüveskedés." (Gyerek 4)

„Én annak örülök, hogy egyből csinálom, bármit kell megoldani, és ennek van köze a Játszóházhoz ... segít a munkahelyen megoldani a problémákat, megtanulni a feladatokat, segít a gyereknek segíteni leckében, tanulásban, iskolai rajz-technika feladatokban." (Gyerek 1)

\section{Programok - tábor - élmények}

A csoport kialakításakor evidens tény volt, hogy ezeknek a gyermekeknek nagy szükségük van különböző programokra, lehetőségekre, amik enyhítik a család anyagi körülményei miatti deprivációjukat. Ami kiemelendő, hogy ezt a törekvést, szándékot a megkérdezettek egyértelműen visszajelezték. A csoport által nyújtott rendszeres, illetve alkalmi programok jelentősen csökkentették az otthoni helyzetből fakadó hátrányaikat, olyan lehetőségekhez juttatta őket a csoport, amelyek egyébként iskola vagy család által nem történtek volna meg gyermekkoruk során. Fontos megjegyezni, hogy olyan programokat is megemlítettek, amiért gyermekként nem feltétlenül lelkesedtek, de visszatekintve mégis említésre méltónak, azaz fontosnak tartják, ilyen például a múzeumlátogatás. 


\section{TANULMÁNY}

A visszaemlékezésekben erőteljesen megjelent a közös mese alkotása, kitalálása és megvalósítása, mint több foglalkozáson átívelő munkamód több interjúban is megjelent. Számukra a kitalálásba, alkotás folyamatába való bevonódás, vagy annak a lehetősége, hogy irányító, meghatározó szerepbe kerülhettek, új volt, meglepő volt és ettől emlékezetes is. A táborok kapcsán a KI MIT TUD-ok, vetélkedők, tinidiszkók, bulik minden interjúban megjelenő élmények, az éjszakai bátorságpróbák, számháborúk mellett.

„A szegénység, amit elvett tőlem, azt a Játszóház és táborai visszaadták.” (Gyerek 2)

„Ha elmehettünk, megnyugvás volt, nem hiába voltunk ilyen rossz sorsúak. A Játszóház menekülés volt. Tábort szerettem, mert ott ott lehetett aludni. Bátorságpróba nagyon jó volt. Megnyugvás, hogy kiszabadulás a mindennapokból, a kilátástalanságból, hogy mindig ugyanaz van, ugyanaz a szar van." (Gyerek 4)

\section{Közösség}

A közösség a többségnek azt a megtartó erőt jelentette, amely abból eredt, hogy mások is hasonló problémákkal küzdenek, hasonló cipőben járnak. Úgy volt ez fontos az interjúk alapján a megkérdezettek számára, hogy nem hangsúlyozódott ez ki az egyes alkalmakon vagy a táborokban, de mint mögöttes tudás támpontot jelentett a gyermekek fejében. A visszaemlékezések alapján ez a tudat erős volt, minden interjúban elhangzott. Olyan egyértelmű volt számukra ez a hovatartozás, identitásuk részévé vált és viszonyítási pontot adott. Mivel legtöbbjük egy pár utcából álló településrészen lakott, ez a kapcsolat megmaradt a csoport felbomlása után is. A lokalitás felbomlása után a legtöbb család elvesztette a lakhatását, és olcsóbb lakhatási megoldások miatt más részére költözött a városnak, vagy a város környéki agglomerációban találtak maguknak lakhatást, így a csoporttagok közötti kapcsolat ennek a változásnak a hatására felbomlott, meglazult, majd megszűnt. Mostanra élő, rendszeres kapcsolat nincs a csoporttagok között, laza, a szociális média felületén van csak kapcsolatuk egymással.

„Olyanokkal ismerkedhettem meg, akik hasonló körülmények közül jöttek”. (Gyerek 5)

„Mert egy csapat voltunk, nem az utcán lengtünk, tengtünk, linkeskedtünk, hanem csináltunk valamit és hülyéskedtünk". (Gyerek 1) 


\title{
TANULMÁNY
}

Az egyik interjú résztvevője saját helyzete, háttere miatt pedig a csoporttagok másságát emelte ki. Számára az elfogadás megtanulásának, a más élethelyzetek megismerésének és megértésének a terepe volt a csoport. Ahogy korábban már elhangzott, a csoportba járó gyermekek többsége mélyszegény, hátrányos helyzetű családokból érkezett a csoportba, de nem mindenki, fontosnak tartottam olyan narratívát, visszaemlékezést is megismerni, aki nem ebbe a közegbe tartozott.

\begin{abstract}
„Olyan emberekkel találkozhattam, akikkel normál életben nem találkozom, iskolában sem voltam kapcsolatban roma gyerekekkel ... kitágult a világ... Elején nekem nagyon furcsa volt, csúnya beszéd vagy hangoskodás, veszekedés, volt, akinek dühkitörései voltak, ezek le lettek kezelve, de annak ez elfogadása, hogy ez van és próbál változtatni és lenyugszik, ez nekem meghatározó volt ... lett változás.” (Gyerek 5)
\end{abstract}

\section{Összegzés}

A vizsgált csoportfolyamat hatásának az elemzéséhez elengedhetetlen a kontextus értelmezése. A rendszerváltás utáni gazdasági és társadalmi változások nagyban befolyásolták, meghatározták a csoportba járó gyermekek és családjaik életét. A rendszerváltás utáni megugró munkanélküliség, lakhatási és anyagi problémák komoly nehézségek elé állították a családokat, bizonytalanná tették vagy ellehetetlenítették a gyermekek szükségleteinek a kielégítését. A Családsegítő Szolgálat által létrehozott gyermekcsoportban a kialakult programelemek és programcélok, a szakemberek kompetenciái a csoport működését a rendszerváltás után kialakuló szociális szolgáltató rendszer keretén belül, a szociális szakma mint professzió segítségével, a szociális munka alapvető szakmai értékeiből kiindulva jött létre. Direkt eszköznek tekinthetők a különböző készségfejlesztő kézműves foglalkozások, játékok. Tudásés ismeretbővítésnek a különböző külső helyszíneken megvalósuló programok és a táborok. A csoporthoz tartozás megtartó ereje, a csoportra való támaszkodás a mindennapokban nyújtott a gyermekek számára megtartó és megerősítő funkciót. Az őket körülvevő valóság normalizálása, élhetővé tétele, a vezetők stabil jelenléte szintén nagyon fontos eleme volt ennek a komplex programnak. A gyermekvédelmi komplex programok lényege, hogy a gyermekeket az őket körülvevő közeggel együttesen, különös tekintettel a családjukra, támogassa, segítse. A komplexitás, a nyitott hozzáállás, az önkéntesség, a stabil jelenlét és elfogadás alapértékei mentén meg tudott valósulni az a fajta bevonódása a gyermekeknek a csoportba, ami kiindulópontot és alapot adott a hatékony csoportmunkához és kézzel fogható, megragadható eredményekkel tudott hozzájárulni a csoporttagok és családjuk életéhez.

A csoport, mint terápiás segítségnyújtási modellben elhelyezhető csoport a csoporttagok számára megtartó, megerősítő hatásával segítette a csoporttagok felnőtt 


\section{TANULMÁNY}

életének az alakulását. A csoportban megtanult készségekre, értékekre és tudásokra támaszkodhattak gyermek- és kamaszkorukban. Felnőttként is vissza-vissza tudtak nyúlni a csoportélményekhez magánéletükben és munkájukban. A gyermekcsoport direkt és indirekt eszközökkel, a csoportvezetők közös összehangolt működésével sikeresen reagált a gyermekeket körülvevő társadalmi valóságra. Olyan értékek közvetítése, készségfejlesztése által, és megtartóerőt biztosítva ezeknek a gyermekeknek, amelyek hatása a megkérdezettek elmondása után kihatott felnőtt életükre. Ez a fajta komplex, prevenciós szemléletű, a gyermeket nem önmagában, hanem környezetével együtt kezelő szemlélet és megközelítés sikeresen ötvözte a különböző csoportmodellek hatásait.

1. ábra. A gyermekcsoport működését meghatározó szempontok

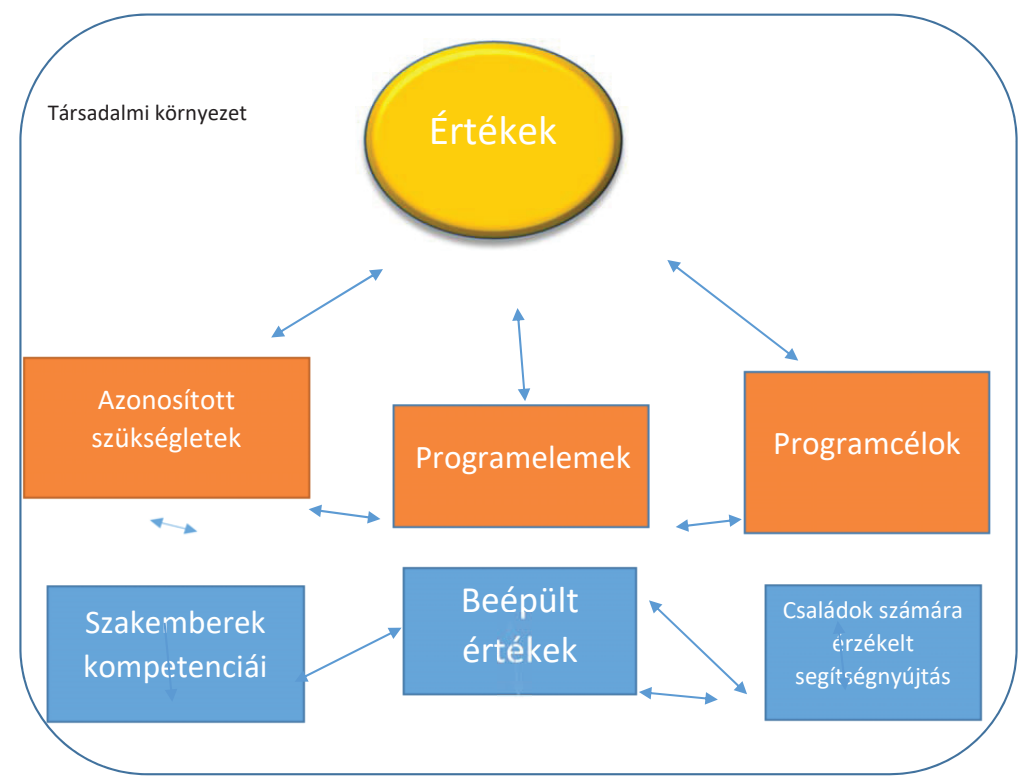

Forrás: Saját szerkesztés

A rendelkezésre álló dokumentumok másodelemzése és az interjúk alapján elmondható, hogy a szakemberek által akkor megfogalmazott célok, célkitüzések a csoporttal kapcsolatban, illetve visszatekintve, a csoport működésének az erősségei, amitől a csoport valóban akkor és ott tudott támaszt, segítséget nyújtani a csoportba járó gyermekeknek, megjelent a megkérdezett volt csoporttagokkal készült interjúkban. A fókuszcsoportban elhangzottak alapján összességében megállapítható, hogy a csoportvezetők szerint a csoportnak a mintaadás, az élmények átadása 


\section{TANULMÁNY}

mellett a legfontosabb funkciója az a fajta holding funkció volt, amely a gyermekek megtartását célozta, stabilitást és kiszámíthatóságot és folyamatosságot jelentett a csoporttagok számára. A csoportos beszélgetés összegzéseként elmondható, hogy a csoport kialakulása, a kezdetek sokkal mélyebben vésődtek a résztvevők emlékébe, mint annak a vége. A csoport kifulladása, a csoport körüli burok eltűnése kevésbé tudott kidomborodni a beszélgetésben. A végén magára maradó csoportvezető egyedül elfogyott, elfáradt és ez a folyamat a csoport végét is jelentette. Ebből következik, hogy az ilyen, éveken át működő csoportok akkor lehetnek sikeresek, stabilak, ha nem egy-két emberre, hanem több, közösséget alkotó csoportvezetők összességére támaszkodnak. A beszélgetés alatt egyértelműen kikristályosodott, hogy a holding funkciót minden csoportvezető nagyon fontosnak tartotta, tudatosan vagy tudattalanul biztosítva ezzel a gyermekeknek, hogy adott egy erős, identitást, biztonságot és stabilitást nyújtó csoport. A csoport ereje, kulcsa a megtartó erő volt, amely körbevette ezeket a gyermekeket, egy biztos pont az életükben tíz éven át. A változó csoportvezetői kör olyan vezetői burkot hozott létre a csoport körül, ahol az elkerülhetetlen változások ellenére is stabilitást, biztonságot kaptak ezek a gyermekek. A holding, a megtartó erő fontossága, jelentősége végigvonult a csoport működésének különböző időszakain. A realizálható világ, a közös megértése a résztvevőket körülvevő világnak, és ennek a valóságnak az elfogadása megtartóerőnek és segítségnek bizonyult akkor is, ha változtatni ezen a valóságon a csoport nem tudott. Természetesen nem tudott a csoport minden gyermeknek minden problémájában segíteni, sőt épp ellenkezőleg. A csoportba járó gyermekek sok problémával rendelkező családokban éltek, a mindennapi krízisekre, nehézségekre és feszültségekre a családsegítő a rendelkezésére álló források mentén egy komplex ellátást igyekezett biztosítani. Ettől még a problémák halmaza nem oldódott meg, a csoport ebben a konfliktusokkal, krízisekkel, nehézségekkel teli világban tudott egy biztos pont lenni a gyermekek számára. Ez a biztos pont a legnagyobb eredménye a csoport működésének. Olyan szakmai közeg vette körül ezt a csoportot, ahol a változások ellenére meg tudott maradni a csoport, máshol ugyan, más vezetőkkel, de a csoport identitását és erejét adó közeg megmaradt. A direkt és nem direkt eszközökkel, a játékokkal, közös tevékenységekkel a csoporttagok olyan készségekre, tudásra és tapasztalatokra tettek szert, amit hasznosítani tudtak felnőttkorukban is akár munkájukban, akár gyermekükkel kapcsolatban. A kirándulások, külső programok, nyári táborok az élményszerzésen túl a csoporthoz való tartozást erősítették, a csoportot mint közösséget összekovácsolták. Az interjúk alapján elmondható, hogy a csoport célkitűzéseinek megfelelően olyan hátteret, bázist tudott nyújtani a tagok számára, amely segítette őket társadalmi hátrányaik leküzdésében, a beilleszkedésben és a mindennapokban. A gyermekvédelem a rendszerváltás óta küzd a gyermekeket érő különböző veszélyek megelőzésével rendszerszinten, számtalan modellprogram célozza a különböző veszélyeztetettségek kialakulását, megelőzését. Ugyanakkor az a fajta komplex, nem egyénekben, hanem egész családokban gondolkodó szakmai 


\section{TANULMÁNY}

munka nem tudott elterjedni, megszilárdulni a Gyvt. elfogadása utáni magyar gyermekvédelmi ellátórendszerben. A kialakuló gyermekvédelmi struktúrában a csoport jellegéből adódóan már nem a családsegítők asztalára tartozott, átkerült az intézményi átalakításokkal párhuzamosan a gyermekjóléti szolgálatokhoz, ahol nem tudott tovább működni. A gyermekjóléti szolgálatok a magas esetszám és fluktuáció miatt nem tudták tovább vinni egy ilyen jellegű csoport működtetését. A csoport működése annak illusztris példája a mai magyar gyermekvédelmi rendszer számára, hogy a gyermekjóléti prevenció egy komplex szolgáltatási keretrendszerbe ágyazottan tudja elérni célját és változást indukálva rövid és hosszabb távon a gyermekek és a családok életében. Ennek része a szociális munka direkt és indirekt eszközeinek egymás mellett való alkalmazása és a szakemberek széles körű együttműködése. A csoport és az őt körülvevő családsegítő működése pozitív irányba változtatott a csoportba járó családok életén. Kell-e ennél több?

\section{Irodalom}

Andorka R. - Spéder Zs. (1994): Szegénység a 90-es évek elején. In: Andorka R. Kolosi T. - Vukovich Gy. (szerk.): Társadalmi riport. TÁRKI, Budapest, 74-106. (elektronikus verzió, készült 2006-ban https://adatbanktest.tarki.hu/adatbankh/kutjel/pdf/a904.pdf)

Csanádi G. - Csizmady A. - Kőszeghy L. - Tomay K. (2006): Belső-erzsébetvárosi rehabilitáció. In: Tér és Társadalom. 20(1): 73-92.

Darvas Á. - Tausz K. (2002): A gyermekszegénység és társadalmi kirekesztődés. http://3sz.hu/sites/default/files/uploaded/darvas_agnes-tausz_katalin_-_gyermekszegenyseg_es_tarsadalmi_kirekesztodes.pdf (utolsó letöltés ideje: 2020. 09. 20.)

Gábos A. - Szivós P. (2004): Szegénység Magyarországon az EU-csatlakozás küszöbén. In: Kolosi T. - Tóth I. Gy. - Vukovich Gy. (szerk.): Társadalmi riport. TÁRKI, Budapest, 96-117.

Gábos A. - Szivós P. (2006): A gyermekszegénység és néhány jellemzője Magyarországon. In: Kolosi T. - Tóth I. Gy. - Vukovich Gy. (szerk.): Társadalmi riport. TÁRKI, Budapest, 204-228.

Hegyesi G. - Talyigás K. - Visy E. (1990): Szociális Kollégium alakult Budapest VII. kerületében. ESÉLY, Budapest, 1990/1.

http://www.esely.org/kiadvanyok/1990_1/informaciok.pdf (utolsó letöltés ideje: 2020. 09. 20.)

Jenkins, H. (2006): A rendszer kezelése. Animula, Budapest.

Kende, B. H. (2003): Gyermekpszichodráma. Osiris, Budapest. 


\section{TANULMÁNY}

Kerezsi K. (1996): A társadalompolitika válasza a krízishelyzetben lévő családok problémáira. In: Kerezsi K. (szerk.): Gyermek - Család - Társadalom. Szociális munka gyermekes családokkal. Kézikönyv. Hilscher Rezső Szociálpolitikai Egyesület és az ELTE Szociológiai Intézet Szociálpolitikai Tanszéke könyvsorozata, Budapest.

Köhler K. - Palotai I. (1999): A Játszóház - szociális csoportmunka gyerekekkel. ELTE, TáTK, Szakdolgozat.

Sági M. (2009): Társadalmi folyamatok a rendszerváltás után. https://ofi.oh.gov.hu/tudastar/jelentes-magyar/tarsadalmi-folyamatok

1997. évi XXXI. törvény a gyermekek védelméről és a gyámügyi igazgatásról https://net.jogtar.hu/jogszabaly?docid=99700031.tv\#lbj0idedd1 